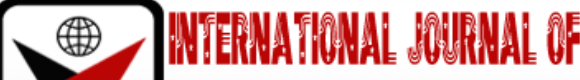

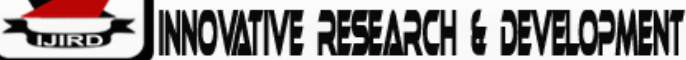

ISSN 2278 - 0211 (Online)

\section{Analysis of Factors Affecting Breeder to Buy Clothes (Pangangguy Sapi Sonok) in Pamekasan District, Indonesia}

\begin{tabular}{|c|}
\hline Moh Zali \\
Lecturer, Department of Agriculture, University of Madura, Indonesia \\
A. Yudi Heryadi \\
Lecturer, Department of Agriculture, University of Madura, Indonesia \\
Selvia Nurlaila \\
Lecturer, Department of Agriculture, University of Madura, Indonesia \\
Rudi Hariyanto \\
Head, Department of Technical Service Unit (UPT) Waru, \\
Animal Husbandry and Food Security, Pamekasan Regency, Indonesia \\
Isnain Bustaram \\
Lecturer, Department of Economic Management, University of Madura, Indonesia
\end{tabular}

\begin{abstract}
:
This research was conducted using a questionnaire method using accidental sampling technique to 68 consumers who happened to be at Warung Taccek Sapi Sonok. Analysis of the data obtained was in the form of qualitative and quantitative analysis. Qualitative analysis is the interpretation of data obtained in research and the results of data processing that have been carried out by providing information and explanations, while quantitative analysis includes validity, reliability, multiple linear regression analysis, analysis of the coefficient of determination $\left(R^{2}\right)$ and hypothesis testing. namely: F-test and t-test.

The results of this study indicate that the independent variables consisting of product, price, promotion and distribution simultaneously or partially have a positive and significant effect on consumer decisions in buying Pangangguy Sapi Sonok at Warung Taccek Sapi Sonok Pamekasan. And the independent variable that has the most dominant influence on the dependent variable is the product with a t-table value of 5.338. While the coefficient of determination ( $R$ square) was obtained 0.907, this means that the breeder decisions can be explained by the four variables of product, price, promotion and distribution by $90.7 \%$ while the remaining $9.3 \%$ is influenced by other factors not included in this study.
\end{abstract}

Keywords: Sapi sonok, product, price, distribution and breeder decisions

\section{Introduction}

Pamekasan Regency is one of the districts on the island of Madura. The agricultural sector plays an important role as the main source of livelihood for the Madurese people. Sutoko, et al. (1998) stated that the livelihoods of Madura Island residents are farmers $( \pm 60 \%)$, traders $( \pm 5 \%)$, laborers $( \pm 19 \%)$, entrepreneurs $( \pm 2 \%)$, breeders $( \pm 2 \%)$, fishermen $( \pm$ $10 \%)$.), and employees ( $\pm 2 \%$ ), while Adib (2011) states that 70 - $80 \%$ of the main livelihoods of the Madurese still depend on the agricultural sector (the rest are livestock, trade, maritime (fishing, fishery and shipping), handicraft business, and a business to manufacture sharp weapons.

There are two activities that develop in Madura in the field of livestock culture, namely the karapan sapi and the sonok sapi culture (Kutsiyah, et al. 2017). Accompanying the cultural event accompanied by these instruments are: (a) tongtong (kentongan made from bamboo sticks or bamboo roots); (b) the okol orchestra (an art commonly performed to accompany fighting events and other events with instruments in the form of three kentongan with red, black, and white decorative motifs on the edge of the gap and at both ends, a xylofon called a ghambhang, a pair of small cymbals from iron which is called kerca, and a straight flute of bamboo called soleng); (c) saronen (a typical Madurese instrument in the form of a cone from a teak tree with six holes in a row in front and one in the back; the saronen orchestra is usually associated with a cow (during karapan sapi), with a horse (for ritual ceremonies at sacred graves or wedding parties. ), with certain household rituals, as well as with mask dances that precede certain rituals); (d) gamelan (an orchestra consisting mainly of metallophones and two-skinned ghendang, also known in Madura as tabbhuwan, kleningan or kalèningan, kelèningan, and ghamellan.

Based on the results of observations, the majority of Pamekasan people really like to buy sonok sapi clothes (Panggangguy Sapi Sonok: Madura) for contests or beauty cows in Madura culture, especially sonok sapi lovers (Zali, 2018a). Furthermore, Nurlaila, et al. (2012) said that the sonok sapi business is one of the businesses with promising prospects. Panggangguy is the primary requirement for sonok sapi to participate in a display cattle contest. Primary needs 
are needs that absolutely must be met and cannot be replaced with others, because if a need is not met, cows will look less beautiful and attractive. Sapi Sonok panggangguy always follows the times, with this cooking trend it makes the panggangguy look less stiff, comfortable to wear and eye-catching for sapi sonok lovers.

Warung Taccek Sapi Sonok is one of the Panggangguy sapi Sonok stores that sell various types of Panggangguy, ranging from heifers to adult cow's. While the models vary, not only for accessories, but also for national contests and also for cultural events. Warung Taccek Panggangguy Sapi Sonok Pamekasan has a difference with other sellers in the City of Pamekasan, the difference is that at Warung Taccek Panggangguy Sapi Sonok Pamekasan, it can accept orders for the panggangguy that the breeders want. If the breeder does not match the model provided by Warung Taccek Panggangguy Sapi Sonok Pamekasan, the breeder can order the model the breeder wants. This Warung Taccek Panggangguy Sapi Sonok Pamekasan is located in Waru Barat Village, which of course this place can be said to be strategic because it is located in Pamekasan where many people pass. In addition, Warung Taccek is located on the edge of the highway and is not so deep, so it is easy to see even by passersby.

Current models and materials are nowadays if you look back to the models and materials of the past, it's just that the now modified ones are cooler and nicer. There are many trends that are followed by the Indonesian nation, including adopting trends from Europe and Korea. Especially now that it cannot be denied that everyone uses social media, from that social media there are many public figures who are followed by the trend of calling. This is one of the driving forces for the rapid development of the Panggangguy model.

In its marketing technique, Warung Taccek Panggangguy Sapi Sonok Pamekasan does both offline and online. Where online marketing is carried out on social media, including WhatsApp and Instagram, and for offline marketing, namely placing posters in front of Warung Taccek. In sales techniques, producers use face to face methods with language that is easily understood by breeders and a polite attitude. In addition to direct sales, Warung Taccek Panggangguy Sapi Sonok Pamekasan also sells online where breeders can buy Panggangguy through social media, this is done by Warung Taccek Panggangguy Sapi Sonok Pamekasan in order to make it easier for breeders to buy Panggangguy.

Warung Taccek Panggangguy Sapi Sonok Pamekasan not only sells panggangguy but also can accept orders from breeders, this makes it easy for breeders who need a grill that suits the tastes of each breeder. Starting from the model of the Panggangguy, the size of the Panggangguy, even for the materials, breeders can choose according to their taste. This advantage is much in demand by breeders just before Eid because breeders want a special Panggangguy and sometimes breeders want a Panggangguy that is uniform with the cows that are owned by one farmer, so that it makes breeders interested in ordering Panggangguy at Warung Taccek Panggangguy Sapi Sonok Pamekasan.

In running its business, Warung Taccek Panggangguy Sapi Sonok Pamekasan has several problems, including those regarding the product, where the products offered by Warung Taccek Panggangguy Sapi Sonok Pamekasan have poor durability so that the age of the products produced does not last long. In addition, the product price set by Warung Taccek Panggangguy Sapi Sonok Pamekasan cannot be reached by all groups so this will cause problems with product price competitiveness, because considering that besides Warung Taccek Panggangguy Sapi Sonok Pamekasan there are still many market competitors who have similar businesses to Warung Taccek Panggangguy Sapi Sonok Pamekasan especially located in the City of Pamekasan.

With the existence of competitors, Warung Taccek Panggangguy Sapi Sonok Pamekasan should also maximize product promotion which will affect the breeder's buying decision, in this case Warung Taccek Panggangguy Sapi Sonok Pamekasan is less active in promoting products such as lack of advertising which only exists in the village area of Waru Barat. In addition, Warung Taccek Panggangguy Sapi Sonok Pamekasan has a space that can be said to be narrow, so that breeders experience difficulties in choosing the pelangguy models. A comfortable place will have a positive impact on the breeder's decision to buy an item.

The business of Warung Taccek Panggangguy Sapi Sonok Pamekasan is a company that is engaged in the product of Panggangguy and also the importance of the variables that can influence the breeders' decision to buy the Sapi Sonok. Based on the background of the problem above, the main problems are: a). Do product, price, promotion and distribution factors simultaneously influence the breederto buy panggangguy at Warung Taccek Panggangguy Sapi Sonok Pamekasan?, B). From the factors mentioned above, which factor has the most dominant influence on breeders to buy Panggangguy at Warung Taccek Panggangguy Sapi Sonok Pamekasan? 


\subsection{Framework}

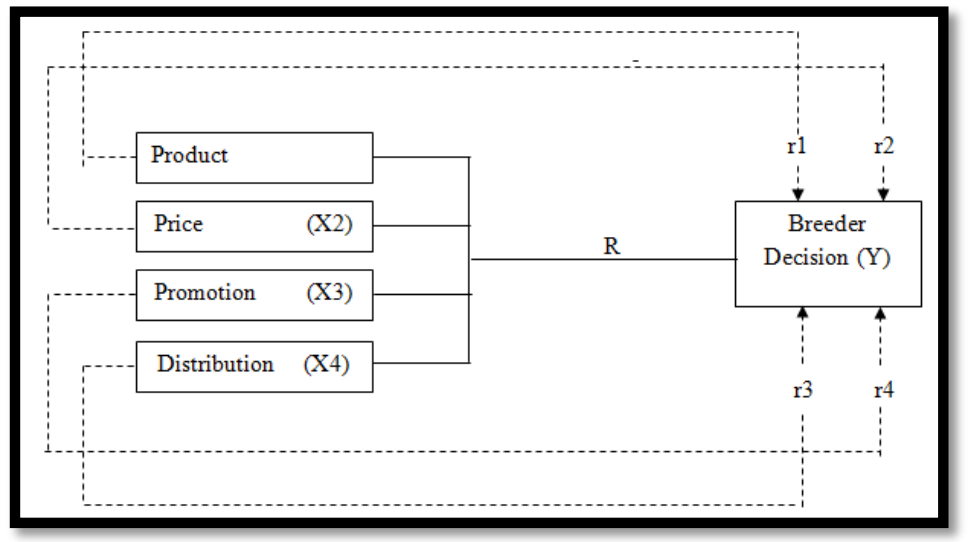

Figure 1: Research Frameworks

The thought frame was made to facilitate the presentation of the stages of this research implementation. The framework describes the relationship of the independent variables, in this case Product (X1), Price (X2), Promotion (X3) and Distribution (X4) on the dependent variable, namely Breeder Decision (Y).

Description:

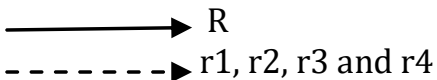

$\mathrm{R}=$ The correlation coefficient is used to measure the influence of the independent variables, namely Product (X1), Price (X2), Promotion (X3), and Distribution (X4) simultaneously on the dependent variable, namely Breeder Decision (Y). r1 = Measuring the influence of Product (X1) on Breeder Decisions (Y). As for assessing the product (X1), it can be measured by the following indicators:

- Durability

- Perceived quality

- Aesthetics or aesthetics

r2 = Measuring the effect of price (X2) of the Breeders Decisions (Y). As for assessing Price (X2) it can be measured by the following indicators:

- Affordability of Prices

- Product Price Competitiveness

- Discounts

r3 = Measuring the influence of Promotion (X3) on Breeders Decisions (Y). As for assessing Promotion (X3) it can be measured by the following indicators:

- Advertising

- Sales Promotion

- $\quad$ Face to face selling (Personal selling)

r4 = Measuring the influence of Distribution (X4) on Breeders decisions (Y). As for assessing distribution (X4) it can be measured by the following indicators:

- $\quad$ Strategic shop location

- Transportation

- $\quad$ Service level

With these indicators, which will be made in the form of questions or statements and distributed to the breeders of Warung Taccek Panggangguy Sapi Sonok Pamekasan. And the data is what ultimately finds or produces the value of the product, price, promotion and distribution of the Breeders decision.

\section{Research Methodology}

\subsection{Research Location}

The research location is to determine the factors that influence breeders to buy Panggangguy at the Warung Taccek Panggangguy Sapi Sonok Pamekasan which is located in Waru Barat Village, Pamekasan Regency, Madura, East Java.

\subsection{Types of Research}

This type of research is an associative (relationship) research. According to Sugiyono (2006) associative research is research that aims to determine the relationship between two or more variables. This research has the highest level when compared to descriptive and comparative research. With this research it will be possible to build a theory that can function to explain, predict, and control a symptom. Thus, this type of research is an associative type of research and the authors use the method of distributing or distributing questionnaires to breeders who buy pangangguy at Warung Taccek Panggangguy Sapi Sonok Pamekasan. 


\subsection{Testing of Data Collection Instruments}

\subsubsection{Validity Test}

The validity test is used to measure the degree of permanence in research about the actual content or meaning being measured. The validity test will be carried out by calculating the correlation coefficient between subjects on the question item with the score obtained from the questionnaire results, namely by looking for the correlation coefficient (r) of each question and compared with the critical value of the correlation table (r). Test the validity of the data using the product moment correlation method (Pearson correlation) (Sugiyono, 2002: 277) with the following formula:

$$
\underset{\sqrt{[}}{\mathrm{r}_{\mathrm{xy}}}=\frac{\mathrm{n} \sum \mathrm{XY}-\sum \mathrm{X} \sum \mathrm{Y}}{\left.\left.\mathrm{X}^{2}-\left(\sum \mathrm{X}^{2}\right)\right]\left[n \sum \mathrm{Y}\right)^{2}\right]}
$$

Description:

$\mathrm{Rxy} \quad=$ Correlation between variables $\mathrm{X}$ and $\mathrm{Y}$

$\mathrm{X} \quad$ = Independent variable

$\mathrm{Y} \quad=$ Dependent variable

$\mathrm{n} \quad=$ Number of respondents

The test criteria are:

$\mathrm{r}$ count $>\mathrm{r}$ table $\longrightarrow$ valid

$\mathrm{r}$ count $<\mathrm{r}$ table $\longrightarrow$ not valid

Data is said to be valid if $r$ count is greater ( $>$ ) than $r$ table. In addition, the data is also said to be valid if it has a correlation coefficient $>0.30$ (Sugiyono, 2011: 126). Thus, all the questions or statements can be used and can be trusted to collect the required data. Another opinion said that the instrument criteria are valid if the correlation value (Pearson correlation) is positive, and the correlation probability value [sig. (2-tailed)] <significant level (a) is 0.05 (Journal of Azwar Juliandi: 2007)

\subsubsection{Reliability Test}

Reliability test as a tool to measure a questionnaire which is an indicator of a variable or construct. A questionnaire is said to be reliable or reliable if a person's answer to a question is consistent or stable over time (Imam Ghozali, 2005: 41). Meanwhile, according to Sugiyono (2006: 137) a reliable instrument is an instrument that when used several times to measure the same object, will produce the same data. In this reliability test with the Cronbach Alpha statistical test, it is known that a variable is said to be reliable if it provides a Cronbach Alpha value> 0.6.

Testing the reliability of the measuring instrument in this study using the reliability method alpha $(\alpha)$ or called the Cronbach Alpha method (Nasution, 2001: 23):

$$
a=\frac{k r}{1+(k-1) r}
$$

Description:

$\mathrm{a}=$ Reliability coefficient

$\mathrm{k}=$ The average correlation coefficient between variables

$r \quad=$ The number of variables in the equation

\subsection{Hypothesis Testing}

\subsubsection{Uji Hipotesis}

Hypothesis testing is used to determine the significance of each independent factor on the dependent factor contained in the model. Hypothesis testing is conducted in the form of simultaneous regression testing ( $\mathrm{F}$ test) and partial regression testing ( $\mathrm{T}$ test).

$\mathrm{F}=\frac{R^{2} / k}{\left(1-R^{2}\right) /(n-k-1)}$

Description :

$\mathrm{R}^{2} \quad=$ Multiple correlation coefficients have been found

$\mathrm{k} \quad=$ Number of independent variables

$\mathrm{n} \quad=$ Number of samples

$\mathrm{F} \quad=\mathrm{F}$ count to be compared with $\mathrm{F}$ table

$$
t=\frac{b_{i}-b_{0}}{S b_{i}}
$$

Description:

$b_{i} \quad=$ coefficients to $\mathrm{i}$.

$b_{0} \quad=$ the hypothesized i parameter.

$s b_{i} \quad=$ standard error. $b_{i}$.

The formula for the limit of the hypothesis is as follows: 
$\mathrm{H}_{\mathrm{a}}: \mathrm{b}_{\mathrm{i}}=0$, there is no significant effect between $\mathrm{X}$ and $\mathrm{Y}$

$\mathrm{H}_{\mathrm{a}}: \mathrm{b}_{\mathrm{i}} \neq 0$, there is a significant influence between $\mathrm{X}$ and $\mathrm{Y}$

By comparing tcount and ttable at a 0.05 , according to Sugiyono (2002: 117) t test decision making is as follows:

- tcount <ttable, then $\mathrm{Ha}$ is accepted and $\mathrm{H} 1$ is rejected, meaning that the independent variable cannot explain the dependent variable.

- $\quad$ tcount> ttable, then $\mathrm{Ha}$ is rejected and $\mathrm{H} 1$ is accepted, meaning that the independent variable can explain the dependent variable.

\section{Research Results and Discussion}

\subsection{Description of Warung Taccek Sapi Sonok}

Warung Taccek Panggangguy Sapi Sonok Pamekasan is an exclusive shop that sells panggangguy Sapi sonok with various types, ranging from heifers and adult cows. The panggangguy offered by Warung Taccek Panggangguy Sapi Sonok Pamekasan are in the form of necklaces, horn covers, headbands, anklets, pangonong and other panggangguy sapi sonok. Warung Taccek Panggangguy Sapi Sonok Pamekasan is different from other sellers in the City of Pamekasan, the difference is that Warung Taccek Panggangguy Sapi Sonok Pamekasan can accept orders for the panggangguy that the breeders want. If the farmer does not match the model provided by Warung Taccek Panggangguy Sapi Sonok Pamekasan, the breeder can order the model the breeder wants. Meanwhile, these products are produced directly and designed by craftsmen designers by limiting the same model.

Warung Taccek Panggangguy Sapi Sonok Pamekasan has been running the Sapi sonok power bread business since 2008 which was founded by Mr. Ramli. Warung Taccek Panggangguy Sapi Sonok Pamekasan is located in Waru Barat Village, Pamekasan Regency. Over time, Warung Taccek Panggangguy Sapi Sonok Pamekasan continues to make efforts to improve in terms of quality and human resources. This is the owner's commitment to make Warung Taccek Panggangguy Sapi Sonok Pamekasan as a professional business for making Sapi Sonok with standard quality products.

\subsection{Characteristics of Respondents}

After conducting the research, namely by distributing questionnaires to 68 respondents with 17 statement items in each questionnaire, the results of the study in the form of data were entered and grouped according to their characteristics. Based on the results of data grouping or tabulation of research data, the distribution of respondents according to each characteristic of the respondent is obtained so that the number and percentage of respondents in each of the existing characteristics can be found. The characteristics of the respondents in this study were classified based on gender, age, education level and occupation.

\subsubsection{Characteristics of Respondents Based on Gender}

The characteristics of the Farmer Taccek Panggangguy Sapi Sonok Pamekasan based on gender can be seen in Table 1:

\begin{tabular}{|c|c|c|c|}
\hline No & Gender & Number & Percentage \\
\hline 1. & Male & 50 & $74 \%$ \\
\hline 2. & Female & 18 & $26 \%$ \\
\hline \multicolumn{2}{|c|}{ Total } & 68 & $100 \%$ \\
\hline
\end{tabular}

Table 1: Characteristics of Respondents Based on Gender

Data Source: The Data Is Processed from Attachment 1

Based on Table 1 above, it can be seen that the respondents are male with a total of 18 respondents or about $26 \%$. Meanwhile, respondents who were female were 50 respondents or around $74 \%$ of the total. This shows that the characteristics of the largest respondents based on gender are female respondents.

\subsubsection{Characteristics of Respondents by Age}

The characteristics of the breeders in Warung Taccek Panggangguy Sapi Sonok Pamekasan based on age can be seen in Table 2:

\begin{tabular}{|c|c|c|c|}
\hline No & Age & Number & Percentage \\
\hline 1. & $<30$ year & 32 & $47 \%$ \\
\hline 2. & $30-40$ year & 24 & $35 \%$ \\
\hline 3. & $>40$ year & 12 & $18 \%$ \\
\hline \multicolumn{2}{|c|}{ Total } & 68 & $100 \%$ \\
\hline
\end{tabular}

Table 2: Characteristics of Respondents by Age

Data Source: The Data Is Processed From Attachment 1

Based on Table 2 above, it can be seen that the largest respondent age level is those under 30 years old with 32 respondents or about $47 \%$ of the total number of respondents. While the smallest age level of respondents is those over 40 years old with a total of 12 respondents or about $18 \%$ of the total number of respondents. The rest were 24 respondents 
or about $35 \%$ aged 30-40 years. This shows that the characteristics of the largest respondents based on age are those who are under 30 years old. The average sonok cattle farmer is equivalent to a productive age of around 30 years old (Zali, 2018b)

\subsubsection{Characteristics of Respondents Based on Education Level}

The characteristics of the farmer in the Warung Taccek Panggangguy Sapi Sonok Pamekasan based on the level of education can be seen in Table 3:

\begin{tabular}{|c|c|c|c|}
\hline No & Education Level & Number & Percentage \\
\hline 1. & Elementary school & 0 & $0 \%$ \\
\hline 2. & Junior High school & 6 & $9 \%$ \\
\hline 3. & High school & 34 & $50 \%$ \\
\hline 4. & Diploma & 10 & $15 \%$ \\
\hline 5. & Bachelor & 18 & $26 \%$ \\
\hline \multicolumn{2}{|c|}{ Total } & 68 & $100 \%$ \\
\hline
\end{tabular}

Table 3: Characteristics of Respondents Based on Education Level Data Source: The Data Is Processed from Attachment 1

Based on Table 3 above, it can be seen that the largest respondent's education level is High school with a total of 34 respondents or about 50\%. Meanwhile, the lowest level of education is junior high school with a total of 6 respondents or about $9 \%$. The rest are Diploma level with a total of 10 respondents or about $15 \%$ and Bachelor degree with a total of 18 respondents or about $26 \%$. This shows that the characteristics of the largest respondents based on education level are those with high school education.

\subsubsection{Characteristics of Respondents by Occupation}

The characteristics of the breeders at Warung Taccek Panggangguy Sapi Sonok Pamekasan by occupation can be seen in Table 4:

\begin{tabular}{|c|c|c|c|}
\hline No & Occupation & Number & Percentage \\
\hline 1. & Civil Servant & 18 & $26 \%$ \\
\hline 2. & Private employees & 8 & $12 \%$ \\
\hline 3. & Entrepreneur & 30 & $44 \%$ \\
\hline 4. & Others & 12 & $18 \%$ \\
\hline \multicolumn{2}{|c|}{ Total } & 68 & $100 \%$ \\
\hline
\end{tabular}

Table 4: Characteristics of Respondents by Occupation

Data Source: The Data Is Processed from Attachment 1

Based on Table 4 above, it can be seen that the highest level of employment of respondents is self-employed with 30 respondents or about 44\%, while the smallest level of employment is private employees total 8 respondents or around $12 \%$. The rest are civil servants with a total of 18 respondents or about 26\%, and others with a total of 12 respondents or about $18 \%$. This shows that the characteristics of the largest respondents based on work are those who work as entrepreneurs. According to Zali (2018c), breeders in Pamekasan Regency are breeder and entrepreneurs who try to manage a breeder system based on kinship and conventional maintenance patterns.

\subsection{Research Data}

Research data related to this research variable can be seen from appendices 2-5-8-11-14. The research data contains the respondents' answers to each dimension of the research variables which are used as questions in the research questionnaire.

\section{Discussion}

\subsection{Validity Test Results}

From the results of the calculation of the validity test on the independent variables and the dependent variable consisting of Product (X1), Price (X2), Promotion (X3), Distribution (X4) and Breeder's Decision (Y) as many as 17 items, of which 17 items will be compared. With the value of $r$ table with a significant level of $0.5 \%$ to find out the valid level of each indicator which will be described below: 


\subsubsection{Products (X1)}

\begin{tabular}{|c|c|c|c|c|}
\hline Independent Variable (X) & Indicator & r Count & r Table & Description \\
\hline \multirow{3}{*}{ Product (X1) } & Durability & 0,315 & 0,235 & Valid \\
\cline { 2 - 5 } & $\begin{array}{c}\text { Quality } \\
\text { Impression }\end{array}$ & 0,582 & 0,235 & Valid \\
\cline { 2 - 5 } & Aesthetics & 0,440 & 0,235 & Valid \\
\hline
\end{tabular}

Table 5: Results of the Validity Test of Independent Variables (X1)

Data source: Data Processed from Attachment 4

Based on the validity test table above, it shows that all indicators used to measure the Product variable (X1) have a calculated $r$ value $>r$ table (0.235). From these results indicate that all indicators of Product variable (X1) are valid.

\subsubsection{Price (X2)}

\begin{tabular}{|c|c|c|c|c|}
\hline Independent Variable (X) & Indicator & r Count & r Table & Description \\
\hline \multirow{3}{*}{ Price (X2) } & Affordability of Prices & 0,438 & 0,235 & Valid \\
\cline { 2 - 5 } & $\begin{array}{c}\text { Product Price } \\
\text { Competitiveness }\end{array}$ & 0,497 & 0,235 & Valid \\
\cline { 2 - 5 } & Discounts & 0,444 & 0,235 & Valid \\
\hline
\end{tabular}

Table 6: Results of the Validity Test of Independent Variables (X2)

Data Source: Data Processed from Attachment 7

Based on the validity test table above, it shows that all indicators used to measure the price variable (X2) have a calculated $r$ value $>r$ table (0.235). From these results indicate that all indicators of the Price variable (X2) are valid.

\subsubsection{Promotion (X3)}

\begin{tabular}{|c|c|c|c|c|}
\hline $\begin{array}{c}\text { Independent Variable } \\
(\mathbf{X})\end{array}$ & Indicator & r Count & r Table & Description \\
\hline \multirow{3}{*}{ Promotion (X3) } & Advertisement & 0,408 & 0,235 & Valid \\
\cline { 2 - 5 } & Sales promotion & 0,467 & 0,235 & Valid \\
\cline { 2 - 5 } & Face-to-Face Sales & 0,517 & 0,235 & Valid \\
\hline
\end{tabular}

Table 7: Results of the Validity Test of Independent Variables (X3)

Data Source: Data Processed From Attachment 10

Based on the validity test table above, it shows that all indicators used to measure the Promotion variable (X3) have a calculated $r$ value $>r$ table $(0.235)$. From these results indicate that all indicators of the Promotion variable (X3) are valid.

\subsubsection{Distribution (X4)}

\begin{tabular}{|c|c|c|c|c|}
\hline Independent Variable (X) & Indicator & r Count & R Table & Description \\
\hline \multirow{3}{*}{ Distribution (X4) } & Strategic Store Location & 0,454 & 0,235 & Valid \\
\cline { 2 - 5 } & Transportation & 0,715 & 0,235 & Valid \\
\cline { 2 - 5 } & Service Level & 0,321 & 0,235 & Valid \\
\hline
\end{tabular}

Table 8: Results of the Validity Test of Independent Variables (X4)

Data Source: Data Processed from Attachment 13

Based on the validity test table above, it shows that all indicators used to measure the distribution variable (X4) have a calculated $r$ value $>r$ table $(0.235)$. From these results indicate that all indicators of the Distribution variable (X4) are valid.

\subsubsection{Breeder Decision (Y)}

\begin{tabular}{|c|c|c|c|c|}
\hline Dependent Variable (Y) & Indicator & r Count & r Table & Description \\
\hline \multirow{4}{*}{ Breeder Decision (Y) } & introduction of Needs & 0,422 & 0,235 & Valid \\
\cline { 2 - 5 } & Search Information & 0,805 & 0,235 & Valid \\
\cline { 2 - 5 } & Alternative Evaluation & 0,523 & 0,235 & Valid \\
\cline { 2 - 5 } & Buying decision & 0,562 & 0,235 & Valid \\
\cline { 2 - 5 } & Post-Purchase Consumption & 0,480 & 0,235 & Valid \\
\hline
\end{tabular}

Table 9: Test Results of the Validity of Bound Variables (Y)

Data Source: Data Processed from Attachment 16 
Based on the validity test table above, it shows that all indicators used to measure the Breeder Decision variable (Y) have a calculated $r$ value $>r$ table $(0.235)$. From these results indicate that all indicators of the Breeder Decision variable (Y) are valid.

\subsection{Reliability Test}

Reliability testing is a test tool used to show the extent to which a measurement result is relatively consistent. The technique used to measure reliability is by using Cronbach Alpha, where the instrument is said to be reliable if it has a greater Cronbach alpha coefficient (>) 0.60 . Overall reliability test results can be seen in the following table:

\begin{tabular}{|c|c|c|}
\hline $\begin{array}{c}\text { Results of the Reliability Variable (X) and Variable } \\
\text { (Y) Test Results }\end{array}$ & \multirow{2}{*}{ Description } \\
\hline Variable & Cronbach Alpha & \\
\hline Product (X1) & 0,776 & Reliable \\
\hline Price (X2) & 0,611 & Reliable \\
\hline Promotion (X3) & 0,660 & Reliable \\
\hline Distribution (X4) & 0,750 & Reliable \\
\hline Breeder Decision (Y) & 0,760 & Reliable \\
\hline
\end{tabular}

Table 10: Reliability Test Results of Independent and Bound Variables

Data source: Data processed from appendices 4-7-10-13-16

Based on the reliability test table above, it shows that each of the independent and dependent variables has a Cronbach alpha of more than $0.60(\alpha>0.60)$ which consists of Product (X1) 0.776, Price (X2) 0.611, Promotion (X3) 0.660, Distribution (X4) 0.750 and Breeder Decision (Y) 0.760. So, it can be concluded that all variables X and Y are reliable and can be analyzed further. The results of Zali's research, et al. (2020) This is what makes the taccek stall business as a provider of sonok beef feed and nutrition can be used as a promising business opportunity for the continuity of the local culture of sonok cattle.

\subsection{Qualitative Analysis}

To get an overview of the results of the respondent's answers, the writer can present the results of the respondents' answers based on the frequency of answers as shown in the following tables:

\subsubsection{Product (X1)}

\begin{tabular}{|c|c|c|c|c|c|c|c|}
\hline \multirow{2}{*}{$\begin{array}{c}\text { Respondents' } \\
\text { Answers }\end{array}$} & \multirow{2}{*}{ Score } & \multicolumn{6}{|c|}{ Product Variables (X1) } \\
\cline { 3 - 8 } & & \multicolumn{2}{|c|}{ Item 1 } & \multicolumn{2}{|c|}{ Item 2 } & \multicolumn{2}{c|}{ Item 3 } \\
\cline { 3 - 8 } & & $\mathbf{F}$ & $\mathbf{\%}$ & $\mathbf{F}$ & $\mathbf{\%}$ & $\mathbf{F}$ & $\mathbf{\%}$ \\
\hline Very Not Good & 1 & - & - & - & - & - & - \\
\hline Not good & 2 & 10 & 14,7 & - & - & 2 & 2,9 \\
\hline Good enough & 3 & 15 & 22,0 & 7 & 10,3 & 23 & 33,8 \\
\hline Good & 4 & 25 & 36,8 & 35 & 51,5 & 29 & 42,7 \\
\hline Very good & 5 & 18 & 26,5 & 26 & 38,2 & 14 & 20,6 \\
\hline Total & & 68 & 100 & 68 & 100 & 68 & 100 \\
\hline
\end{tabular}

Table 11: Respondents' Answers Frequency for Product Variables (X1)

Data Source: Data Processed from Attachment 3

Based on the Table 11 above, the Product indicator (X1) which consists of Durability (item 1) as many as 10 or $14.7 \%$ of respondents answered not good, 15 or $22.0 \%$ of respondents answered Good enough, 25 or $36.8 \%$ of respondents answered Good and 18 or $26.5 \%$ of respondents answered very good. As for the impression of good quality (item 2) as many as 7 or $10.3 \%$ of respondents answered Good enough, 35 or $51.5 \%$ of respondents answered Good and 26 or $38.2 \%$ of respondents answered very Good. Furthermore, on aesthetics (item 3) as much as 2 or $2.9 \%$ of respondents answered not good, 23 or 33.8\% of respondents answered Good enough, 29 or 42.7 respondents answered Good and 14 or $20.6 \%$ of respondents answered very Good. 


\subsubsection{Price (X2)}

\begin{tabular}{|c|c|c|c|c|c|c|c|}
\hline \multirow{2}{*}{$\begin{array}{c}\text { Respondents' } \\
\text { Answers }\end{array}$} & \multirow{2}{*}{ Score } & \multicolumn{6}{|c|}{ Price Variable (X2) } \\
\cline { 3 - 8 } & & $\mathrm{F}$ & Item 1 & \multicolumn{2}{|c|}{ Item 2 } & \multicolumn{2}{c|}{ Item 3 } \\
\cline { 3 - 8 } & 1 & - & - & - & - & - & - \\
\hline Strongly Disagree & 2 & 4 & 5,9 & 1 & 1,5 & 5 & 7,3 \\
\hline Disagree & 3 & 23 & 33,8 & 17 & 25,0 & 20 & 29,4 \\
\hline Quite Agree & 4 & 25 & 36,8 & 29 & 42,6 & 28 & 41,2 \\
\hline Agree & 5 & 16 & 23,5 & 21 & 30,9 & 15 & 22,1 \\
\hline Strongly agree & & 68 & 100 & 68 & 100 & 68 & 100 \\
\hline Total & & &
\end{tabular}

Table 12: Respondents' Answer Frequency for Price Variable (X2)

Data Source: Data Processed from Attachment 6

Based on table 4:12 above, the Price indicator (X2) which consists of Price Affordability (item 1) as many as 4 or $5.9 \%$ of respondents answered disagree, 23 or $33.8 \%$ of respondents answered quite agree, 25 or $36.8 \%$ of respondents answered agree and 16 or $23.5 \%$ of respondents answered strongly agree. As for Price Competitiveness (item 2 ) as much as 1 or $1.5 \%$ of respondents answered disagree, 17 or $25.0 \%$ of respondents answered quite agree, 29 or $42.6 \%$ of respondents answered agreed and 21 or $30.9 \%$ of respondents answered strongly agree. Furthermore, on Price Discounts (item 3) as many as 5 or $7.3 \%$ of respondents answered disagree, 20 or $29.4 \%$ of respondents answered quite agree, 28 or 41.2 respondents answered agreed and 15 or $22.1 \%$ of respondents answered strongly agreed.

\subsubsection{Promotion (X3)}

\begin{tabular}{|c|c|c|c|c|c|c|c|}
\hline \multirow{2}{*}{$\begin{array}{c}\text { Respondents' } \\
\text { Answers }\end{array}$} & \multirow{3}{*}{ Score } & \multicolumn{6}{|c|}{ Promotion Variable (X3) } \\
\cline { 3 - 8 } & & Item 1 & \multicolumn{2}{|c|}{ Item 2 } & \multicolumn{2}{c|}{ Item 3 } \\
\cline { 3 - 8 } & & $\mathbf{F}$ & $\mathbf{0}$ & $\mathbf{F}$ & $\mathbf{\%}$ & $\mathbf{F}$ & $\mathbf{\%}$ \\
\hline Very Not Good & 1 & - & - & - & - & - & - \\
\hline Not good & 2 & 9 & 13,2 & 1 & 1,5 & 4 & 5,9 \\
\hline Quite good & 3 & 22 & 32,4 & 11 & 16,2 & 11 & 16,2 \\
\hline Good & 4 & 30 & 44,1 & 32 & 47,0 & 39 & 57,3 \\
\hline Very good & 5 & 7 & 10,3 & 24 & 35,3 & 14 & 20,6 \\
\hline Total & & 68 & 100 & 68 & 100 & 68 & 100 \\
\hline
\end{tabular}

Table 13: The Frequency of Respondents' Answers for Promotion Variables (X3) Data Source: Data Processed from Attachment 9

Based on the Table 13 above, the Promotion indicator (X3) which consists of advertisements (item 1) as many as 9 or $13.2 \%$ of respondents answered not good, 22 or $32.4 \%$ of respondents answered quite good, 30 or $44.1 \%$ of respondents answered good and 7 or $10.3 \%$ of respondents answered very good. Whereas for Sales Promotion (item 2 ) as much as 1 or $1.5 \%$ of respondents answered not good, 11 or $16.2 \%$ of respondents answered quite good, 32 or $47.0 \%$ of respondents answered good and 24 or $35.3 \%$ of respondents answered very agreed. Furthermore, in Face-to-Face Sales (item 3) as many as 4 or $5.9 \%$ of respondents answered not good, 11 or $16.2 \%$ of respondents answered quite good, 39 or 57.3 respondents answered good and 14 or $20.6 \%$ of respondents answered very agreed. nice.

\subsubsection{Distribution (X4)}

\begin{tabular}{|c|c|c|c|c|c|c|c|}
\hline \multirow{2}{*}{$\begin{array}{c}\text { Respondents' } \\
\text { Answers }\end{array}$} & \multirow{2}{*}{ Score } & \multicolumn{6}{|c|}{ Distribution Variables (X4) } \\
\cline { 3 - 8 } & & \multicolumn{2}{|c|}{ Item 1 } & \multicolumn{2}{|c|}{ Item 2 } & \multicolumn{2}{c|}{ Item 3 } \\
\cline { 3 - 8 } & & F & \% & F & \% & F & \% \\
\hline Very Not Good & 1 & - & - & - & - & - & - \\
\hline Not good & 2 & - & - & 2 & 2,9 & 3 & 4,4 \\
\hline Quite good & 3 & 25 & 36,8 & 25 & 36,8 & 19 & 27,9 \\
\hline Good & 4 & 22 & 32,3 & 30 & 44,1 & 33 & 48,6 \\
\hline Very good & 5 & 21 & 30,9 & 11 & 16,2 & 13 & 19,1 \\
\hline Total & & 68 & 100 & 68 & 100 & 68 & 100 \\
\hline
\end{tabular}

Table 14: Respondents' Answer Frequency for Distribution Variables (X4) Data Source: Data Processed from Attachment 12

Based on Table 14 above, the distribution indicator (X4) which consists of Strategic Store Locations (item 1) as many as 25 or $36.8 \%$ of respondents answered quite well, 22 or $32.3 \%$ of respondents answered good and 21 or $30.9 \%$ of respondents answer very good. As for transportation (item 2) as much as 2 or $2.9 \%$ of respondents answered not good, 25 or $36.8 \%$ of respondents answered quite good, 30 or $44.1 \%$ of respondents answered good and 11 or $16.2 \%$ of respondents answered very good. Furthermore, at the Service Level (item 3) as many as 3 or $4.4 \%$ of respondents 
answered not good, 19 or $27.9 \%$ of respondents answered quite good, 33 or 48.6 respondents answered good and 13 or $19.1 \%$ of respondents answered very good.

\subsubsection{Breeder's Decision (Y)}

\begin{tabular}{|c|c|c|c|c|c|c|c|c|c|c|c|}
\hline \multirow{3}{*}{$\begin{array}{c}\text { Respondents' } \\
\text { Answers }\end{array}$} & \multirow{3}{*}{ Score } & \multicolumn{10}{|c|}{ Variable Breeder Decisions (Y) } \\
\hline & & \multicolumn{2}{|c|}{ Item 1} & \multicolumn{2}{|c|}{ Item 2} & \multicolumn{2}{|c|}{ Item 3} & \multicolumn{2}{|c|}{ Item 4} & \multicolumn{2}{|c|}{ Item 5} \\
\hline & & $\mathbf{F}$ & $\%$ & $\mathbf{F}$ & $\%$ & $\mathbf{F}$ & $\%$ & $\mathbf{F}$ & $\%$ & $\mathbf{F}$ & $\%$ \\
\hline Strongly Disagree & 1 & - & - & - & - & - & - & - & - & & \\
\hline Disagree & 2 & - & - & - & - & 5 & 7,3 & 2 & 3,0 & - & - \\
\hline Quite Agree & 3 & 5 & 7,4 & 17 & 25,0 & 17 & 25,0 & 16 & 23,5 & 11 & 16,2 \\
\hline Agree & 4 & 37 & 54,4 & 31 & 45,6 & 35 & 51,5 & 16 & 23,5 & 48 & 70,6 \\
\hline Strongly agree & 5 & 26 & 38,2 & 20 & 29,4 & 11 & 16,2 & 34 & 50,0 & 9 & 13,2 \\
\hline Total & & 68 & 100 & 68 & 100 & 68 & 100 & 68 & 100 & 68 & 100 \\
\hline
\end{tabular}

Table 15: Respondents' Answers Frequency for Breederr's Decision Variable (Y)

Data Source: Data Processed from Attachment 15

Based on the Table 15 above, the dependent variable is Farmer Decision (Y) which consists of Introduction to Needs (item 1) as many as 5 or $7.4 \%$ of respondents answered quite agree, 37 or $54.4 \%$ of respondents answered agree and 26 or $38.2 \%$ respondents answered strongly agree. Meanwhile, for information seeking (item 2) 17 or $25.0 \%$ of respondents answered quite agree, 31 or $45.6 \%$ of respondents answered agree and 20 or $29.4 \%$ of respondents answered strongly agree.

Furthermore, in Alternative Evaluation (item 3) as many as 5 or $7.3 \%$ of respondents answered disagree, 17 or $25.0 \%$ of respondents answered quite agree, 35 or $51.5 \%$ of respondents answered agreed and 11 or $16.2 \%$ of respondents answered strongly agree. As for the purchase decision (item 4) as much as 2 or $3.0 \%$ of respondents answered disagree, 16 or $23.5 \%$ of respondents answered quite agree, 16 or $23.5 \%$ of respondents answered agreed and 34 or $50.0 \%$ of respondents answered strongly agree. And for Post Purchase Consumption (item 5) as much as 11 or $16.2 \%$ of respondents answered quite agree, 48 or $70.6 \%$ of respondents answered agreed and 9 or $13.2 \%$ of respondents answered strongly agree.

\subsection{Quantitative Analysis}

\subsubsection{Multiple Linear Regression Analysis}

Multiple linear regression testing is used to determine the level of influence of the independent variables (product, price, promotion and distribution) on the dependent variable (breeder decisions). Based on the test, the results obtained can be presented in the following table:

\begin{tabular}{|c|c|c|c|}
\hline \multirow[t]{2}{*}{ Model } & \multicolumn{2}{|c|}{$\begin{array}{l}\text { Unstandardized } \\
\text { Coefficients }\end{array}$} & \multirow{2}{*}{$\begin{array}{c}\begin{array}{c}\text { Standardized } \\
\text { Coefficients }\end{array} \\
\text { Beta }\end{array}$} \\
\hline & B & Std. Error & \\
\hline 1 (Constant) & 0,230 & 0,176 & \\
\hline (X1) Product & 0,492 & 0,092 & 0,436 \\
\hline (X2) Price & 0,187 & 0,073 & 0,176 \\
\hline (X3) Promotion & 0,265 & 0,080 & 0,250 \\
\hline (X4) Distribution & 0,157 & 0,058 & 0,173 \\
\hline
\end{tabular}

Table 16: Results of Multiple Linear Regression Analysis Data Source: Data Processed from Attachment 17

Based on the results of data processing, a multiple regression equation can be prepared as follows:

$\mathrm{Y}=0,230+0,492 \mathrm{X}_{1}+0,187 \mathrm{X}_{2}+0,265 \mathrm{X}_{3}+0,157 \mathrm{X}_{4}+\mathrm{e}$

Based on the results of the regression equation above, several things can be interpreted as follows:

- Constant value $(\alpha)$ 0.230. This means that if Product (X1), Price (X2), Promotion (X3) and Distribution (X4) are equal to zero, then the Breeder Decision to buy Panggangguy at Warung Taccek Panggangguy Sapi Sonok Pamekasan is 0.230 .

- $\quad$ Value of Product Variable 0.492

The product regression coefficient (X1) is 0.492, which means that every increase in X1 is 1 unit, then the Breeder Decision (Y) at Warung Taccek Panggangguy Sapi Sonok Pamekasan has increased by 0.492 . Assuming the other variables are constant.

- Value of Price Variable 0,187

Price regression coefficient (X2) of 0.187 means that every increase in X2 is 1 unit, then the Breeder Decision (Y) at Warung Taccek Panggangguy Sapi Sonok Pamekasan has increased by 0.187. Assuming the other variables are constant.

- Value of Promotion Variable 0,265 
Promotion regression coefficient (X3) of 0.265 means that every increase in X3 is 1 unit, then the Breeder Decision (Y) at the Warung Taccek Panggangguy Sapi Sonok Pamekasan has increased by 0.265. Assuming the other variables are constant.

- $\quad$ Value of Distribution Variable 0.157

The distribution regression coefficient (X4) is 0.157, which means that every increase in X4 is 1 unit, then the Breeder Decision (Y) at Warung Taccek Panggangguy Sapi Sonok Pamekasan has increased by 0.157. Assuming the other variables are constant.

\subsection{Coefficient of Determination $R^{2}$}

The coefficient of determination is used to determine the ability of the independent variable to explain the dependent variable. The higher the coefficient of determination the better. The results of the determination can be seen in the following table:

\begin{tabular}{|c|c|c|c|c|}
\hline \multicolumn{5}{|c|}{ Model Summary } \\
\hline Model & R & R Square & $\begin{array}{c}\text { Adjusted R } \\
\text { Square }\end{array}$ & $\begin{array}{c}\text { Std. Error of the } \\
\text { Estimate }\end{array}$ \\
\hline 1 & $0,952^{\text {a }}$ & 0,907 & 0,901 & 0,15081 \\
\hline
\end{tabular}

Table 17: Results of the Coefficient of Determination

Data source: Data Processed from Attachment 17

Based on the results of the analysis presented in Table 17, it is known that the $\mathrm{R}$ value is 0.952 . This means that the relationship between the dimensions of the independent variable and the dimensions of the dependent variable is 95.2\%. From these figures it can be concluded that the relationship between the independent variable and the dependent variable is very strong.

While the magnitude of $\mathrm{R}^{2}=0.907$ This means that all independent variables (X1, X2, X3, X4) contribute together by $90.7 \%$ to variable $Y$, while the rest is $9.3 \%(100 \%-90.7 \%=9.3 \%)$ is influenced by factors outside this model. Thus, the four independent variables are said to be quite influential on the dependent variable, namely the Breeder Decision to buy Panggangguy at Warung Taccek Panggangguy Sapi Sonok Pamekasan.

\subsection{Hypothesis Test Results}

\subsubsection{Simultaneous Test Analysis (Test F)}

The $\mathrm{F}$ test is used to determine the effect of the independent variable on the dependent variable together. The results of the $\mathrm{F}$ test can be seen in the following table:

\begin{tabular}{|c|c|c|c|c|c|}
\hline \multicolumn{6}{|c|}{ ANOVA $^{\mathrm{a}}$} \\
\hline Model & $\begin{array}{c}\text { Sum of } \\
\text { Squares }\end{array}$ & Df & $\begin{array}{c}\text { Mean } \\
\text { square }\end{array}$ & F & Sig \\
\hline 1 Regression & 14,012 & 4 & 3,503 & 154,018 &, $000^{\mathrm{b}}$ \\
Residual & 1,433 & 63 & 0,023 & & \\
Total & 15,445 & 67 & & & \\
\hline
\end{tabular}

Table 18: F Test Results

Data Source: Data Processed from Attachment 17

From the results of the $\mathrm{F}$ test above, it is obtained that an $\mathrm{F}$ count is 154.018 and if consulted with $\mathrm{F}$ table (attachment 20) it is 2.52. So, it can be concluded that F count 154.018> F table 2.52 with a significance level of 0.000 $<0.05$.

Based on the explanation above, the hypothesis is that Product (X1), Price (X2), Promotion (X3) and Distribution (X4) simultaneously or jointly affect the Breeder Decision (Y) in buying Panggangguy at Warung Taccek Panggangguy Sapi Sonok Pamekasan can be verified.

\subsubsection{Partial Test Analysis (t test)}

The $t$ test is used to determine the effect of the independent variables (Product X1, Price X2, Promotion X3 and Distribution X4) on the dependent variable (Breeder Decision) individually. The $t$ test results can be seen in the following table: 


\begin{tabular}{|c|c|c|c|c|c|}
\hline \multirow{3}{*}{ Model } & \multicolumn{2}{|c|}{ Coefficients $^{\mathbf{a}}$} & \multirow[b]{2}{*}{$\begin{array}{c}\text { Standardized } \\
\text { Coefficients }\end{array}$} & \multirow[b]{3}{*}{$\mathbf{T}$} & \multirow[b]{3}{*}{ Sig } \\
\hline & \multicolumn{2}{|c|}{$\begin{array}{c}\text { Unstandardized } \\
\text { Coefficients }\end{array}$} & & & \\
\hline & B & Std. Error & Beta & & \\
\hline 1 (Constant) & ,230 & ,176 & & 1,308 & ,196 \\
\hline (X1) Product & ,492 & ,092 & ,436 & 5,338 & ,000 \\
\hline (X2) Price & 187 & ,073 & 176 & 2,565 & ,013 \\
\hline (X3) Promotion & ,265 & ,080 & ,250 & 3,299 & ,002 \\
\hline (X2) Distribution & ,157 & ,058 & ,173 & 2,691 & ,009 \\
\hline
\end{tabular}

Table 19: T Test Results

Data Source: Data Processed from Attachment 17

The $t$ table value based on $(\mathrm{df})=(\alpha / 4: \mathrm{n}-\mathrm{k}-1)$ is 2.389 with a significance level of 0.05 . Then it can be seen that the level of influence given by each independent variable on the dependent variable is as follows:

\subsubsection{Partial Test of Product Variables (X1)}

The results of the partial test ( $t$ test) of the Product variable (X1), it is known that the $t$ value is $5.338>t$ table 2.389 with a significance level of $0.000<0.05$. This means that partially the Product variable (X1) has a significant effect on the Breeder Decision variable (Y).

\subsubsection{Partial Price Variable Test (X2)}

The results of the partial test ( $\mathrm{t}$ test) of the price variable (X2), it is known that the $t$ value is $2.565>t$ table 2.389 with a significance level of $0.013<0.05$. This means that partially the price variable (X2) has a significant effect on the Breeder Decision variable (Y).

\subsubsection{Partial Test of Promotion Variable (X3)}

The results of the partial test ( $t$ test) of the Promotion variable (X3), it is known that the $t$ value is $3,299>t$ table 2,389 with a significance level of $0.002<0.05$. This means that partially the promotion variable (X3) has a significant effect on the Breeder Decision variable (Y).

\subsubsection{Partial Test of Distribution Variables (X4)}

The results of the partial test ( $\mathrm{t}$ test) of the distribution variable (X4), it is known that the $t$ value is $2.691>t$ table 2.389 with a significance level of $0.009<0.05$. This means that partially the distribution variable (X4) has a significant effect on the Breeder Decision variable (Y).

From the comparison of the $t$ value and table above, it can be seen that the Product variable (X1) is the independent variable that most dominantly influences the breeder decision to buy Panggangguy at Warung Taccek Panggangguy Sapi Sonok Pamekasan, because it has the highest t value of 5.338.

From the explanation above, it can be concluded that the second hypothesis which states that the product is the most dominant variable influencing the breeder decision to buy panggangguy at Warung Taccek Panggangguy Sapi Sonok Pamekasan can be proven.

\section{Conclusions and Suggestions}

\subsection{Conclusion}

Based on the results of the research and discussion of the factors that influence breeders to buy Panggangguy at Warung Taccek Panggangguy Sapi Sonok Pamekasan, the conclusions of the results of this study are as follows:

- Based on the simultaneous test results (F test) it can be proven that the variable Product (X1), Price (X2), Promotion (X3) and Distribution (X4) simultaneously have a significant effect on the Breeder Decision to buy Panggangguy at Warung Taccek Panggangguy Sapi Sonok Pamekasan.

- $\quad$ Based on the partial test results ( $t$ test) it can be proven that the variable Product (X1), Price (X2), Promotion (X3) and Distribution (X4) partially have a significant effect on the Breeder Decision to buy Panggangguy at Warung Taccek Panggangguy Sapi Sonok Pamekasan.

Product Variable (X1) is the most dominant variable that has a significant effect on Breeder Decision in buying Panggangguy at Warung Taccek Panggangguy Sapi Sonok Pamekasan.

\subsection{Suggestions}

Based on the results of the research and the conclusions described above, the suggestions for the parties related to the results of this study are as follows:

- Warung Taccek Panggangguy Sapi Sonok Pamekasan should maintain and improve the product because the product variable has the most dominant partial effect when compared to other variables. From the research results, it is also expected that the company will continue to pay attention to the dimensions that form product variables such as: product durability, impression of good product quality and product aesthetics.

- Price, Promotion and Distribution variables also have a partial influence on the Breeder Decision in buying Panggangguy at Warung Taccek Panggangguy Sapi Sonok Pamekasan, so it is hoped that the company will 
further improve and re-evaluate the variable that has the smallest contribution, namely the price variable with more attention to dimensions as well.: product price affordability, product price competitiveness and price discounts.

- For future researchers, it is hoped that research will develop and make reference materials or references in conducting research in other research objects.

\section{References}

i. Kutsiyah, F. Zali, M. Risqina, Nurlaila, S.(2017). Skenario Pembibitan Sapi madura di Pulau Madura (Scenario of Madura Cattle Breeding in Madura Island). Jurnal Ilmu Ternak, Juni 2017, Vol.17, No. 1. Universitas Diponegoro Semarang.

ii. Nurlaila, S. (2012). Potret Selintas Sapi Sonok di eks. Kawedanan Waru Kabupaten Pamekasan. MADURANCH: Jurnal Ilmu Peternakan, Vol.9, No. 1. Fakultas Pertanian Universitas Madura

iii. Sugiyono. 2006. Metode Penelitian Administrasi dilengkapi dengan Metode R\&D. CV Alfabeta. Bandung.

iv. Sugiyono. 2008. Metode Penelitian Kuantitatif Kualitatif dan R\&D. CV Alfabeta. Bandung.

v. Sugiyono. 2009. Metode Penelitian Kuantitatif Kualitatif dan R\&D. CV Alfabeta. Bandung.

vi. Zali, M. Nurlaila, S. Heryadi, YA. Syah, AG (2020). PenguatanTeknologi Pendukung Destinasi Budaya Sapi Sonok Di Kabupaten Pamekasan. Akuntansi Bisnis dan Manajemen (ABM), Volume 7 Nomor 1 Halaman 45 -61 Bulan Juli, Tahun 2020 ISSN 2477-6432 E-ISSN 2721-141X

vii. Zali M (2018). The interplay of traditional cultural events and cattle farm: humans and animals as victims of madurese ancient tradition. Adv. Anim.Vet. Sci.6(9): 347.354.

viii. Zali M (2018). Critics for violating animal welfare in the cruel side of culture: indonesian perspectives. Adv. Anim. Vet. Sci. 6(9): 372-379

ix. Zali, M, A. Yudi Heryadi, Selvia Nurlaila, Zaenal Fanani. (2018). Madura cattle agribusiness performance and feasibility in Galis region, Madura. Int. J. Adv. Multidiscip. Res. 5(6): 45-55. DOI:

http://dx.doi.org/10.22192/ijamr.2018.05.06.006 